\title{
Correction to: Fetal growth is associated with CpG methylation in the P2 promoter of the IGF1 gene
}

\author{
Catherine Le Stunff ${ }^{*}$, Anne-Laure Castell ${ }^{2}$, Nicolas Todd ${ }^{1}$, Clémence Mille ${ }^{1}$, Marie-Pierre Belot ${ }^{1}$, Nathalie Frament ${ }^{1}$, \\ Sylvie Brailly-Tabard ${ }^{3}$, Alexandra Benachi ${ }^{4}$, Delphine Fradin ${ }^{5}$ and Pierre Bougnères ${ }^{1}$
}

\section{Correction}

After publication of the original article [1], it came to the publishers' attention that the below author's corrections provided at the proofing stage had been misinterpreted.

1) The title should have read "Fetal growth is associated with CpG methylation in the P2 promoter of the IGF1 gene", and not "Fetal growth is associated with the CpG methylation of the P2 promoter of the IGF1 gene".

2) The first sentence of Fig. 1 caption should have read "CpG-137 methylation correlates negatively with birth length", and not "CpG-137 methylation correlates negatively with height".

3) Additional file 3 legend should have read "Correlation matrix of methylation values (\%) at the $\mathbf{C p G}$ located in the P1 and P2 promoters of the IGF1 gene in newborns patients. Pearson correlation coefficient is indicated in bold, and P value below.", and not "Correlation matrix of methylation values (\%) at the CG located in the P1 and P2 promoters of the IGF1 gene in newborns patients. Pearson correlation coefficient is indicated in bold, and P value below."

4) Additional file 4 legend should have read "Relationship between promoter CpG methylation and genotypes. (A) Methylation at CpGs-137 of the IGF1 P2 promoter is independent from the rs35767 genotypes. (B) Methylation at CpGs-206 and CpG180 in insulin promoter is closely dependent on rs689 alleles.", and not "Relationship between promoter CG methylation and genotypes. (A) Methylation at CpGs-137 of the IGF1 P2 promoter is independent from the rs35767 genotypes. (B) Methylation at CpGs-206 and CpG-180 in insulin promoter is closely dependent on rs689 alleles."

The original article has been updated to reflect these corrections.

\begin{abstract}
Author details
${ }^{1}$ Institut National de la Santé et de la Recherche Médicale U1169, Bicêtre Hospital, Paris Sud University, Le Kremlin-Bicêtre, France. ${ }^{2}$ Service de Médecine des Adolescents, Bicêtre Hospital, Paris Sud University, Le Kremlin-Bicêtre, France. ${ }^{3}$ Service de BiologieMoléculaire et Hormonologie, Bicêtre Hospital, Paris Sud University, Le Kremlin-Bicêtre, France. ${ }^{4}$ Service de Gynécologie-Obstétrique, Antoine Béclère Hospital, Paris Sud University, Clamart, France. ${ }^{5}$ CRCINA, INSERM U1232, Université de Nantes, Nantes, France.
\end{abstract}

Received: 18 May 2018 Accepted: 18 May 2018

Published online: 04 June 2018

\section{Reference}

1. Le Stunff C, Castell A, Todd N, Mille C, Belot M, Frament N, Brailly-Tabard S, Benachi A, Fradin D. Fetal growth is associated with CpG methylation in the P2 promoter of the IGF1 gene. Clin Epigenetics. 2018;10:57. https://doi.org/ 10.1186/s13148-018-0489-9.

* Correspondence: catherine.le-stunff@inserm.fr

${ }^{1}$ Institut National de la Santé et de la Recherche Médicale U1169, Bicêtre

Hospital, Paris Sud University, Le Kremlin-Bicêtre, France

(c) The Author(s). 2018 Open Access This article is distributed under the terms of the Creative Commons Attribution 4.0 International License (http://creativecommons.org/licenses/by/4.0/), which permits unrestricted use, distribution, and reproduction in any medium, provided you give appropriate credit to the original author(s) and the source, provide a link to the Creative Commons license, and indicate if changes were made. The Creative Commons Public Domain Dedication waiver (http://creativecommons.org/publicdomain/zero/1.0/) applies to the data made available in this article, unless otherwise stated. 